\title{
SURVEY OF SCALE INSECTS AND MEALYBUGS ON MANGO TREES AND ECOLOGICAL STUDIES OF INSULASPIS PALLIDULA (GREEN) AT GIZA GOVERNORATE
}

\author{
ABD EL RAZZIK, MAHA I., EVON A. OSMAN, A. M. SERAG and S.S. EL- \\ BADAWEY
}

Plant Protection Research Institute, ARC, Dokki, Giza,

(Manuscript received 9 March 2017)

\begin{abstract}
A survey of scale insects and mealybugs on mango trees (Mangifera indica L.) was carried out in a private mango orchard at El-Saff, Giza Governorate, during two successive years 2014 and 2015. The infestation of mango trees with scale insects and mealybugs was determined. The results indicated that, the mango trees were infested by 12 species of scale insects and mealybugs belonging to four families: Diaspididae, Coccidae, Monophlebidae and Pseudococcidae. From the twice monthly collection, the white mealybug, Icerya seychellarum (Westwod) was the most dangerous and abundant of the collected species followed by Insulaspis pallidula (Green) then Kilifia acuminata (Signoret) and Hemiberlesia lataniae (Signoret). The Maskell scale insect, I. pallidula was selected for further ecological studies on four mango cultivars. The selected four mango cultivars are not equally susceptible to $I$. pallidula infestation. Hendi mango trees cultivar (cv.) were heavily infested and severely damaged, while trees of Fagrikalan cv. are the lowest infestation with I. pallidula. However, the susceptibility levels of mango cultivars to $I$. pallidula could be arranged in descending order as follows: Hendi >Alphonso-Naser > Dabsha > Fagrikalan. Population of $I$. pallidula recorded three generations and three activity peaks per year. In the first year of study three peaks of infestation were recorded in $1^{\text {st }}$ April, mid-July and $1^{\text {st }}$ October, while in the second year 2015, these peaks were recorded during mid-April, mid-August and $1^{\text {st }}$ November. The calculated infestation rates of $I$. pallidula were high in spring, summer and autumn months, whereas, relatively low rate of infestation were recorded with winter months in both years.
\end{abstract}

Keywords: Ecological studies, Insulaspis pallidula, susceptibility, mango trees.

\section{INTRODUCTION}

Mango trees, (Mangifera indica L.) (Anacardiaceae) are considered one of the most popular and economic fruit trees in Egypt and it plays an important role in food industrialization such as juices, which wanted with large amounts to export according to good reputation of Egyptian varieties. Mango occupies the third rank after citrus and grapes from the commercial point of view (El-Masry, 2004). Egypt has several local mango cultivars that produce unique variety of mango fruits. such as Alphonso, 
Baladi, Ewaisi, Zebda, Hendi and Sultani (El-Zohgbi and Mostafa, 2002). Several studies conducted in different Egyptian localities showed that different mango cultivars express varying levels of tolerance to scale insects and mealybugs infestation (Monzer et al., 2006 and Salem et al., 2007). Scale insects and mealy bugs are serious insect pests, attack the mango trees and cause a severely considerable damage in Egypt. These soft scale insects and mealybugs are sucking pest of plant sap and secret large amount of the honey dew which encourage the growth of sooty mold fungi, that consequently reduce the photosynthesis and respiration of plant leaves (Radwan, 2003).

The present work aimed to study the occurrence of scale insects and mealybugs inhabiting mango trees in a private mango orchard located at El-Saff, Giza Governorate, Egypt. Also, ecological studies on the most commonly species was conducted for two successive years, (2014 and 2015).

\section{MATERIALS AND METHODS}

\section{Study site:}

This study was conducted in a private mango orchard (called Fisher orchard) located at El-Saff, Giza Governorate, Egypt. Orchard total area was 200-feddan and contains 2000 trees of more than 10 mango cultivars, are grown. Most trees were planted in 1935 and trees were more than $4 \mathrm{~m}$ high during the time of the study.

\section{Sampling of survey:}

Four local important mango cultivars were chosen (Fagrikalan, AlphonsoNaser, Hendi and Dabsha). The leaves sample collection was carried out twice monthly for two successive years, (2014 and 2015). Three representative trees from each cultivar were chosen randomly and marked. Selected trees were similar in size, shape, height and vegetation. The selected marked trees and four trees adjacent to each of them were excluded from any chemical treatment applied to the rest of the orchard. A sample comprising 10 leaves was collected randomly from each of the four cardinal directions (East, West, North and South) of the middle crown parts from each of the three marked trees for each cultivar i.e. 120 leaves per sample ( 3 trees $\times 4$ directions $\mathrm{x} 10$ leaves). Leaves of each tree were packed separately in paper bags and transferred into the laboratory for carefully inspection in the same day.

In the laboratory, scale insects and mealybugs were identified in department of scale insects and mealybugs. Population densities of the most commonly species of scale insects and mealybugs on Fagrikalan, Alphonso-Naser, Hendi and Dabsha cultivar leaves were estimated on three trees for each cultivar. Total numbers of a live 
nymphs and adults on each leaf were counted and their total numbers for each cultivar on each inspection date were calculated. The number of generations was estimated from half monthly data of total nymphs according to the method mentioned by Assem (1990).

\section{Meteorological data :}

To reveal the relation between climatic condition and fluctuation of $I$. pallidula population, means of daily temperature and relative humidity at Giza Governorate were obtained from the Meteorological Station of the Agricultural Research Center, Egypt and the half monthly mean was calculated.

\section{Statistical analysis :}

All parameters concerning I. pallidula population density on mango leaves were reduced to three-specific means, and these means were used in statistical analysis. All data were evaluated statistically using ANOVA and means compared using Duncan's Multiple Range Test at $\mathrm{P}<0.05)$. The relationship between the population density of $I$. pallidula and both temperature (Maximum and minimum temperature) and relative humidity (R.H.) were tested using simple correlation and multiple regression analysis. All statistical analyses were done using the software package Costat (Costat, 2005).Ref.

\section{RESULTS AND DISCUSSION}

\section{Survey of scale insects and mealybugs :}

Field studies were carried out on scale insects and mealybugs on mango trees during two successive years, (2014 and 2015). The survey of scale insects and mealybugs infesting mango trees indicated that, mango trees were infested by 12 scale insects and mealybugs species: five species belonging to family Diaspididae, three species to family Coccidae, two species to families Monophlebidae and Pseudococcidae. The highest abundant species was Icerya seychellarum (Westwod) (48.14\%) of the total collected species, followed by Insulaspis pallidula (Green) (29.01\%), then Kilifia acuminata (Signoret) (12.74\%) and Hemiberlesia lataniae (Signoret) (8.57\%). The less abundant species were Ceroplastes floridensis (Comstock) (0.49\%), Parlatoria oleae (Colvee) (0.29\%), Aulacaspis tubercularis (Newstead) (0.22\%), Aonidiella aurantii (Maskell) (0.18\%), Planococcus citri (Risso) $(0.11 \%)$, Icerya aegyptiaca (Douglas) $(0.10 \%)$, Pulvinaria vitis (Linnaeus) $(0.08 \%)$ and Planococcus ficus (Signoret) $(0.07 \%)$ (Table, 1$)$. 

STUDIES OF INSULASPIS PALLIDULA (GREEN) AT GIZA GOVERNORATE

Table 1. The collected scale insects that infest mango trees leaves at Fisher mango orchard, Giza Governorate during 2014 and 2015 years.

\begin{tabular}{|c|c|c|c|c|c|c|}
\hline \multirow{2}{*}{ No. } & \multirow{2}{*}{ Insect scientific name } & \multirow{2}{*}{ Family } & \multicolumn{2}{|c|}{$\begin{array}{c}\text { Mean counts/ } \\
120 \text { leaves }\end{array}$} & \multirow{2}{*}{ Total } & \multirow{2}{*}{$\%$} \\
\hline & & & 2014 & 2015 & & \\
\hline 1 & Icerya seychellarum (Westwod) & Monophlebidae & 25873 & 16100 & 41963 & 48.14 \\
\hline 2 & Insulaspis pallidula (Green) & Diaspididae & 12421 & 12852 & 25283 & 29.01 \\
\hline 3 & Kilifia acuminata (Signoret) & Coccidae & 5389 & 5712 & 11101 & 12.74 \\
\hline 4 & Hemiberlesia lataniae (Signoret) & Diaspididae & 3787 & 3686 & 7473 & 8.57 \\
\hline 5 & Ceroplastes floridensis (Comstock) & Coccidae & 268 & 163 & 431 & 0.49 \\
\hline 6 & Parlatoria oleae (Colvee) & Diaspididae & 254 & - & 254 & 0.29 \\
\hline 7 & Aulacaspis tubercularis (Newstead) & Diaspididae & 188 & - & 188 & 0.22 \\
\hline 8 & Aonidiella aurantii (Maskell) & Diaspididae & 60 & 98 & 158 & 0.18 \\
\hline 9 & Planococcus citri (Risso) & Pseudococcidae & 48 & 46 & 94 & 0.11 \\
\hline 10 & Icerya aegyptiaca (Douglas) & Monophlebidae & 89 & - & 89 & 0.10 \\
\hline 11 & Pulvinaria psidii (Linnaeus) & Coccidae & 71 & - & 71 & 0.08 \\
\hline 12 & Planococcus ficus (Signoret) & Pseudococcidae & - & 64 & 64 & 0.07 \\
\hline & & Total & 48448 & 38721 & 87169 & 100 \\
\hline
\end{tabular}

According to these results, the population densities of most serious and abundant species I. pallidula was studied on leaves of four mango cultivars Fagrikalan, Alphonso-Naser, Hendi and Dabsha in this assay.

\section{General trend of population fluctuation of $I$. pallidula on mango trees :}

Results represented in Table, (2) and illustrated in Figure, (1) showed the half-monthly means of nymphs and adults (females) and total population density of $I$. pallidula infesting mango trees in Fisher mango orchard (mixed cultivars), Giza Governorate during 2014 year. Density of $I$. pallidula nymphs on mango leaves was low during December and January, then began to increase gradually to form a small significant peak on $1^{\text {st }}$ April (256 nymphs/10 leaves), then two large approximately equal peaks on mid-July (397 nymphs/10 leaves) and the beginning of October (347 nymphs/10 leaves). Also, three peaks of adult females were observed on mid-April (130 adult females/10leaves), mid-July (186 adult females/10leaves) and mid-October (225 adult females /10leaves). Overall combined numbers of individuals (Nymphs and 
adult females) on mango leaves indicated that activity of $I$. pallidula extended from February to November with a small activity peak on $1^{\text {st }}$ April (380 individuals/10 leaves), peak of intermediate population density during mid-October (551individuals/10leaves) and the large peak on mid-July (583 individuals/10 leaves).

Results of the second year of investigation, (2015) as represented in Table, (3) and Figure, (2) showed that general population trends, number of peaks of nymphs and adult females of $I$. pallidula were similar to those in the previous year, (2014). Density of $I$. pallidula nymphs on mango leaves have significant peak on midAugust (345 nymphs/10 leaves), and two large approximately equal peaks on midApril (375 nymphs/10 leaves) and the beginning of November (379 nymphs/10 leaves). The three peaks of adult females were observed on $1^{\text {st }}$ April (174 adult females/10leaves), mid-August (232 adult females/10 leaves), and $1^{\text {st }}$ November (182 adult females/10leaves). The total numbers of individuals (nymphs and adult females) on mango leaves indicated that activity of $I$. pallidula extended from February to December with three activity peaks on mid-April (516 individuals/10 leaves), midAugust (577individuals/10 leaves) and $1^{\text {st }}$ November (561 individuals /10 leaves).

These results were in agreement with those obtained by Ali, (2010) who recorded that the pre-adult and adult females of Lepidosaphes pallidula (Insulaspis pallidula) had three peaks through the two years of investigation, (2005 and 2006) and the total population of $L$. pallidula had three peaks annually recorded end of winter, spring and autumn seasons. The highest peak recorded at March and the lowest abundance recorded at July. The results of Elwan, (1990) showed that, mango trees were heavily infested by Lepidosaphes pallidula during autumn in El-Qanater ElKhairia, Qalubyia governorate. Hassan, (1998) mentioned that the highest population density of Insulaspis pallidula on mango trees during the two successive years of the investigation was detected in $25^{\text {th }}$ of September in the first year and $10^{\text {th }}$ of March in the second year.

\section{Infestation levels and population densities of $I$. pallidula :}

Population densities of the I. pallidula on leaves of mango cultivars Fagrikalan, Alphonso-Naser, Hendi and Dabsha at the sampling date are shown in tables $(2,3)$ and figures. $(1,2)$. The highest mean number of $I$. pallidula individuals per 10 leaves was found on Hendi cultivar 4679 (2933 nymphs and 1746 adult females) and 4831 (3104nymphs and 1727 adult females) followed by Dabsha 2016 (1266 nymphs and 750 adult females) and 2423 (1557 nymphs and 866 adult females) then Alfanso-Naser 1454 (912 nymphs and 542 adult females) and 1932 (1243nymphs and 689 adult females) and the lastly Fagrikalan 170 (105 nymphs and 65 adult females) and 489 (312 nymphs and 177 adult females) in the two successive 
years, (2014) and (2015), respectively. Accordingly, the order of susceptibility levels of mango cultivars to $I$. pallidula could be arranged in descending order as follows: Hendi (highly susceptible) $>$ Dabsha $>$ Alfanso-Naser $>$ Fagrikalan (highly tolerable). The calculated infestation rates of $I$. pallidula were high in spring, summer and autumn months, whereas, relatively low rates were recorded with winter months in both years. The highest abundance was recorded during October (13.23\%) and August $(11.25 \%)$, while, the lowest abundance was recorded during January (2.43 and 3.20 $\%$ ) in the two successive years, respectively. The overall population densities were not similar among the two studied years, since, the population density of the first year was lower than the second one. This difference in I. pallidula activity is possibly attributed to the variation of the chemical composition (quantitvlly and qualitivlly) of the mango leaves cultivars or weathering conditions.

These differences in the population density between cultivars appeared more pronounced in mid-July where total number of I. pallidula on Hendi cultivar in 2014 year averaged 328 individuals/10 leaves compared with 142, 101 and 12 individuals/10leaves on Dabsha, Alfanso-Naser and Fagrikalan cultivars, respectively. Similarly, average numbers of $I$. pallidula on Hendi cultivar during 2015 year was significantly higher than that on the other three cultivars. 
Table 2. Half monthly mean counts of Insulaspispallidula different stages, at Fisher mango orchard, Giza, Governorate during 2014year.

\begin{tabular}{|c|c|c|c|c|c|c|c|c|c|c|c|c|c|c|c|c|c|c|}
\hline \multirow{3}{*}{$\begin{array}{c}\text { Date of } \\
\text { inspection }\end{array}$} & \multicolumn{14}{|c|}{ Mean number of individuals/10 leaves } & \multirow{3}{*}{ Total } & \multirow{2}{*}{\multicolumn{2}{|c|}{ Temp. }} & \multirow{3}{*}{ RH } \\
\hline & \multicolumn{3}{|c|}{ Fagri- Kalan } & \multicolumn{3}{|c|}{ Alfanso-Naser } & \multicolumn{3}{|c|}{ Hindi } & \multicolumn{3}{|c|}{ Dabsha } & \multicolumn{2}{|c|}{ Total } & & & & \\
\hline & $\mathbf{N}$ & A & Total & $\mathbf{N}$ & A & Total & $\mathbf{N}$ & A & Total & $\mathbf{N}$ & $\mathbf{A}$ & Total & $\mathbf{N}$ & $\mathbf{A}$ & & Max. & Min. & \\
\hline 1-Jan & 2 & 2 & 4 & 7 & 5 & 12 & 25 & 17 & 42 & 11 & 7 & 18 & 45 & 31 & 76 & 18.6 & 10.2 & 68.0 \\
\hline 15-Jan & 2 & 2 & 4 & 12 & 10 & 22 & 38 & 32 & 70 & 16 & 8 & 30 & 68 & 58 & 126 & 21.0 & 11.1 & 50.1 \\
\hline 1-Feb & 3 & 2 & 5 & 18 & 11 & 29 & 59 & 38 & 97 & 23 & 18 & 41 & 103 & 69 & 172 & 20.1 & 10.5 & 59.7 \\
\hline 15-Feb & 3 & 2 & 5 & 24 & 15 & 39 & 77 & 47 & 124 & 33 & 20 & 53 & 137 & 84 & 221 & 20.9 & 11.6 & 62.5 \\
\hline 1-Mar & 3 & 2 & 5 & 29 & 16 & 45 & 92 & 51 & 143 & 40 & 22 & 42 & 164 & 91 & 255 & 23.2 & 13.9 & 44.9 \\
\hline 15-Mar & 4 & 3 & 7 & 36 & 18 & 54 & 115 & 58 & 173 & 50 & 25 & 75 & 205 & 104 & 309 & 24.6 & 13,6 & 53.3 \\
\hline 1-Apr & 5 & 2 & 7 & 45 & 22 & 67 & 144 & 70 & 214 & 62 & 30 & 92 & 256 & 124 & 380 & 26.6 & 14.7 & 46.1 \\
\hline 15-Apr & 4 & 3 & 7 & 40 & 23 & 63 & 131 & 73 & 204 & 56 & 31 & 98 & 232 & 130 & 362 & 30.3 & 17.8 & 45.9 \\
\hline 1-May & 4 & 2 & 6 & 37 & 22 & 59 & 118 & 68 & 186 & 51 & 30 & 81 & 210 & 121 & 431 & 30.3 & 19.9 & 40.5 \\
\hline 15-May & 4 & 2 & 6 & 32 & 21 & 53 & 105 & 67 & 172 & 45 & 30 & 75 & 136 & 120 & 306 & 32.2 & 20.1 & 44.5 \\
\hline 1-Jun & 5 & 3 & 8 & 40 & 19 & 59 & 128 & 61 & 189 & 55 & 26 & 81 & 228 & 109 & 337 & 32.7 & 21.5 & 45.0 \\
\hline 15-Jun & 5 & 3 & 8 & 43 & 26 & 69 & 139 & 84 & 223 & 60 & 36 & 96 & 247 & 149 & 396 & 35.1 & 22.5 & 44.9 \\
\hline 1-Jul & 6 & 3 & 9 & 53 & 29 & 82 & 178 & 93 & 271 & 80 & 40 & 120 & 316 & 165 & 481 & 34.8 & 23.1 & 53.2 \\
\hline 15-Jul & 8 & 4 & 12 & 69 & 32 & 101 & 223 & 105 & 328 & 97 & 45 & 142 & 397 & 186 & 583 & 33.6 & 23.4 & 54.0 \\
\hline 1-Aug & 6 & 3 & 9 & 54 & 31 & 85 & 175 & 100 & 275 & 76 & 43 & 119 & 311 & 177 & 488 & 34.7 & 24.3 & 53.1 \\
\hline 15-Aug & 5 & 3 & 8 & 43 & 30 & 73 & 137 & 96 & 233 & 59 & 42 & 101 & 244 & 171 & 415 & 35.4 & 24.6 & 56.1 \\
\hline 1-Sep & 5 & 3 & 8 & 51 & 27 & 78 & 160 & 87 & 247 & 69 & 38 & 107 & 285 & 155 & 440 & 33.7 & 23.9 & 51.9 \\
\hline 15-Sep & 6 & 4 & 10 & 56 & 33 & 89 & 180 & 106 & 286 & 78 & 46 & 124 & 319 & 189 & 508 & 33.1 & 22.9 & 49.7 \\
\hline $1-0 \mathrm{ct}$ & 7 & 5 & 12 & 61 & 35 & 96 & 195 & 115 & 310 & 84 & 45 & 129 & 347 & 200 & 547 & 29.7 & 19.1 & 55.4 \\
\hline 15-0ct & 6 & 4 & 10 & 57 & 39 & 96 & 184 & 127 & 311 & 79 & 55 & 134 & 326 & 225 & 551 & 28.2 & 19.1 & 51.1 \\
\hline 1-Nov & 5 & 3 & 8 & 48 & 27 & 75 & 156 & 87 & 243 & 67 & 37 & 104 & 277 & 154 & 431 & 26.2 & 16,5 & 53.6 \\
\hline 15-Nov & 3 & 2 & 5 & 25 & 22 & 47 & 80 & 70 & 150 & 34 & 30 & 64 & 142 & 124 & 266 & 22.1 & 14.2 & 64.6 \\
\hline 1-Dec & 2 & 2 & 4 & 20 & 16 & 36 & 63 & 52 & 115 & 27 & 22 & 49 & 112 & 92 & 204 & 23.5 & 13.7 & 57.5 \\
\hline 15-Dec & 1 & 1 & 2 & 10 & 13 & 23 & 31 & 42 & 73 & 14 & 18 & 32 & 56 & 74 & 130 & 20.1 & 11.5 & 56.4 \\
\hline Total & 105 & 65 & 170 & 912 & 542 & 1454 & 2933 & 1746 & 4679 & 1266 & 750 & 2016 & 5216 & 3103 & 8415 & 670.7 & 423.7 & 1262 \\
\hline Average & 4.37 & 2.71 & $7.08^{\mathrm{d}}$ & 38.00 & 22.58 & $60.58^{c}$ & 122.20 & 72.75 & $194.96^{\mathrm{a}}$ & 52.75 & 31.25 & $84.00^{\mathrm{b}}$ & 217.30 & 129.29 & 350.62 & 27.94 & 17.65 & 52.58 \\
\hline \multirow{2}{*}{\multicolumn{4}{|c|}{$\begin{array}{l}F=69.4793 \\
N=N y m p h\end{array}$}} & \multirow{2}{*}{\multicolumn{9}{|c|}{$\begin{array}{l}\mathrm{P}=0.0000 \\
\text { Temp. }=\text { Ter }\end{array}$}} & \multirow{2}{*}{\multicolumn{5}{|c|}{$\begin{array}{l}\text { LSD }_{0.05}=26.6633 \\
\text { R.H. }=\text { Relative Hur }\end{array}$}} & \\
\hline & & & & & & & & & & & & & & & & & & \\
\hline
\end{tabular}




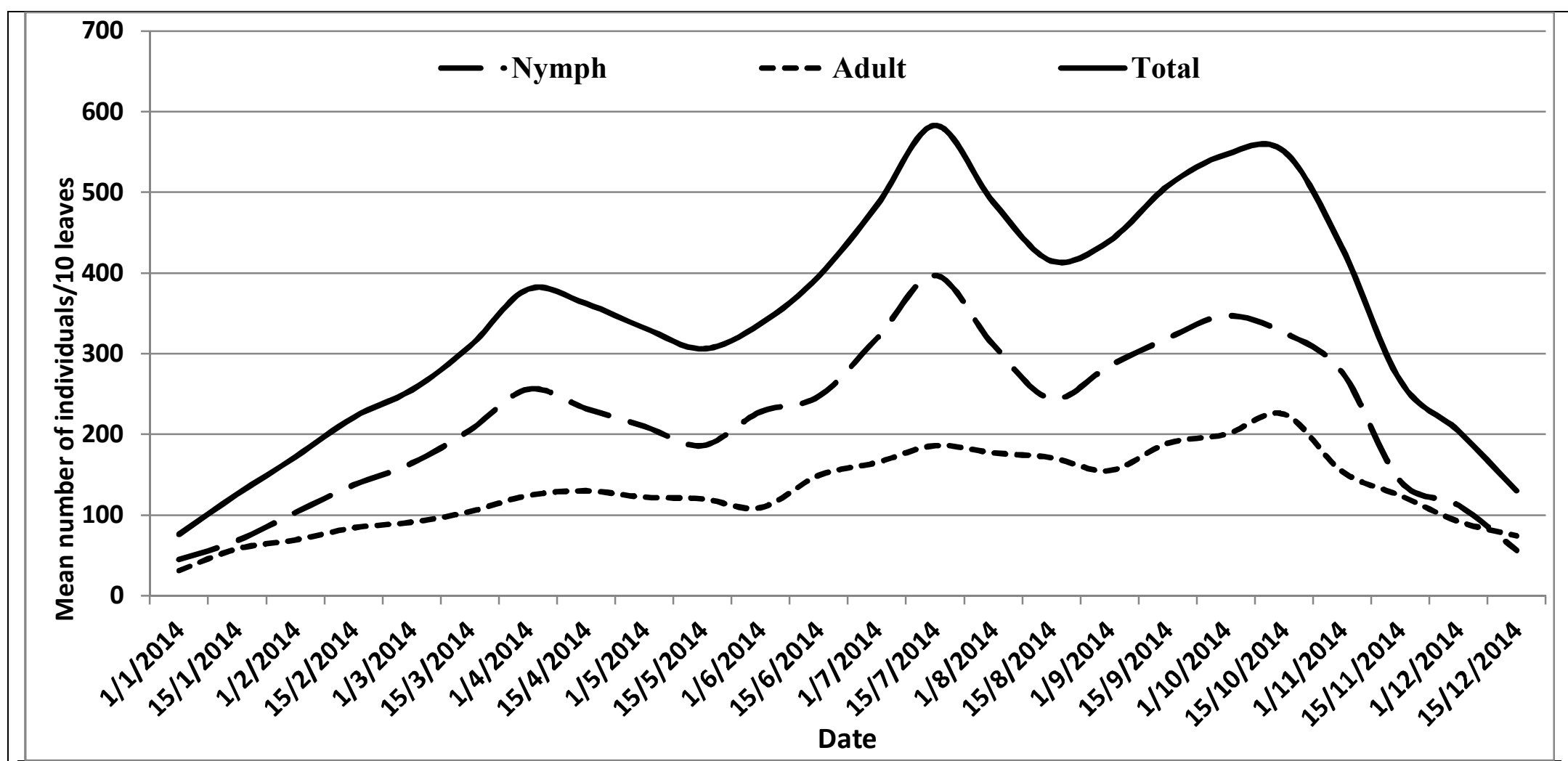

Fig. 1. Half monthly mean counts of Insulaspispallidula different stages, at Fisher mango orchard, Giza, Governorate during 2014 year. 
Table 3. Half monthly mean counts of Insulaspispalliduladifferent stages, at Fisher mango orchard, Giza, Governorate during 2015 year.

\begin{tabular}{|c|c|c|c|c|c|c|c|c|c|c|c|c|c|c|c|c|c|c|}
\hline \multirow{3}{*}{$\begin{array}{c}\text { Date of } \\
\text { inspection }\end{array}$} & \multicolumn{14}{|c|}{ Mean number of individuals $/ 10$ leaves } & \multirow{3}{*}{ Total } & \multirow{2}{*}{\multicolumn{2}{|c|}{ Temp. }} & \multirow{3}{*}{ RH } \\
\hline & \multicolumn{3}{|c|}{ Fagri- Kalan } & \multicolumn{3}{|c|}{ Alfanso-Naser } & \multicolumn{3}{|c|}{ Hindi } & \multicolumn{3}{|c|}{ Dabsha } & \multicolumn{2}{|c|}{ Total } & & & & \\
\hline & $\mathbf{N}$ & $\mathbf{A}$ & Total & $\mathbf{N}$ & A & Total & $\mathbf{N}$ & A & Total & $\mathbf{N}$ & $\mathbf{A}$ & Total & $\mathbf{N}$ & $\mathbf{A}$ & & Max. & Min. & \\
\hline 1-Jan & 4 & 3 & 7 & 17 & 12 & 29 & 44 & 28 & 72 & 21 & 15 & 36 & 86 & 58 & 144 & 15.1 & 8.6 & 51.5 \\
\hline 15-Jan & 5 & 4 & 9 & 18 & 13 & 31 & 46 & 37 & 83 & 23 & 20 & 43 & 92 & 74 & 166 & 20.2 & 11.3 & 49.3 \\
\hline 1-Feb & 6 & 5 & 11 & 22 & 18 & 40 & 57 & 41 & 98 & 29 & 22 & 51 & 114 & 86 & 200 & 20.0 & 10.6 & 41.4 \\
\hline 15-Feb & 7 & 6 & 13 & 28 & 23 & 51 & 70 & 57 & 127 & 36 & 28 & 64 & 141 & 114 & 255 & 18.4 & 9.9 & 57.6 \\
\hline 1-Mar & 11 & 7 & 18 & 43 & 27 & 70 & 107 & 67 & 174 & 54 & 34 & 88 & 215 & 135 & 350 & 23.0 & 13.2 & 58.7 \\
\hline 15-Mar & 13 & 8 & 21 & 54 & 31 & 85 & 134 & 78 & 212 & 67 & 38 & 105 & 268 & 155 & 423 & 24.4 & 13.3 & 48.4 \\
\hline 1-Apr & 15 & 9 & 24 & 60 & 35 & 95 & 150 & 87 & 237 & 75 & 43 & 118 & 300 & 174 & 474 & 24.3 & 14.0 & 48.3 \\
\hline 15-Apr & 19 & 7 & 26 & 75 & 28 & 103 & 187 & 70 & 257 & 94 & 36 & 130 & 375 & 141 & 516 & 28.0 & 15.3 & 41.5 \\
\hline 1-May & 17 & 6 & 23 & 67 & 26 & 93 & 168 & 64 & 232 & 84 & 32 & 116 & 336 & 128 & 464 & 29.2 & 17.3 & 50.3 \\
\hline 15-May & 15 & 5 & 20 & 62 & 21 & 83 & 154 & 53 & 207 & 78 & 27 & 105 & 309 & 106 & 415 & 33.6 & 20.2 & 41.6 \\
\hline 1-Jun & 14 & 5 & 19 & 56 & 18 & 74 & 141 & 45 & 186 & 71 & 23 & 94 & 282 & 91 & 373 & 31.3 & 20.4 & 51.5 \\
\hline 15-Jun & 11 & 6 & 17 & 45 & 23 & 68 & 114 & 58 & 172 & 57 & 29 & 86 & 227 & 116 & 343 & 33.1 & 22.4 & 47.9 \\
\hline 1-Jul & 10 & 8 & 18 & 40 & 32 & 72 & 100 & 79 & 179 & 50 & 39 & 89 & 200 & 158 & 358 & 32.7 & 22.4 & 55.4 \\
\hline 15-Jul & 12 & 9 & 21 & 49 & 36 & 85 & 123 & 88 & 211 & 62 & 44 & 106 & 246 & 177 & 423 & 35.9 & 23.8 & 49.0 \\
\hline 1-Aug & 15 & 11 & 26 & 60 & 40 & 100 & 148 & 102 & 250 & 73 & 52 & 125 & 296 & 205 & 501 & 37.3 & 26.7 & 47.8 \\
\hline 15-Aug & 17 & 12 & 29 & 69 & 46 & 115 & 173 & 116 & 289 & 86 & 58 & 144 & 345 & 232 & 577 & 35.0 & 25.3 & 56.2 \\
\hline 1-Sep & 15 & 11 & 26 & 63 & 42 & 105 & 157 & 105 & 262 & 78 & 52 & 130 & 313 & 210 & 523 & 35.1 & 24.4 & 57.9 \\
\hline 15-Sep & 13 & 10 & 25 & 54 & 39 & 93 & 136 & 97 & 233 & 67 & 48 & 115 & 270 & 194 & 464 & 35.5 & 24.9 & 44.5 \\
\hline 1-Oct & 15 & 7 & 22 & 60 & 29 & 89 & 149 & 74 & 223 & 74 & 37 & 111 & 298 & 147 & 445 & 31.6 & 21.9 & 58.2 \\
\hline 15-Oct & 18 & 8 & 26 & 71 & 32 & 103 & 178 & 81 & 259 & 89 & 40 & 129 & 356 & 161 & 517 & 29.6 & 20.3 & 58.4 \\
\hline 1-Nov & 20 & 9 & 29 & 78 & 36 & 116 & 184 & 92 & 276 & 97 & 45 & 143 & 379 & 182 & 561 & 25.5 & 16.7 & 68.5 \\
\hline 15-Nov & 17 & 8 & 25 & 68 & 34 & 102 & 172 & 86 & 258 & 86 & 43 & 129 & 343 & 171 & 514 & 24.6 & 15.3 & 59.7 \\
\hline 1-Dec & 15 & 8 & 23 & 54 & 26 & 80 & 136 & 66 & 202 & 68 & 33 & 101 & 273 & 133 & 406 & 19.90 & 11.30 & 63.8 \\
\hline 15-Dec & 8 & 5 & 13 & 30 & 22 & 52 & 76 & 56 & 132 & 38 & 28 & 66 & 152 & 111 & 263 & 20.40 & 11.30 & 64.4 \\
\hline Total & 312 & 177 & 489 & 1243 & 689 & 1932 & 3104 & 1727 & 4831 & 1557 & 866 & 2423 & 6216 & 3459 & 9675 & 668.9 & 420.8 & 1271.8 \\
\hline Avarage & 13 & 7.37 & $20.37^{d}$ & 51.79 & 28.71 & $80.5^{c}$ & 129.33 & 71.96 & $201.29^{a}$ & 64.87 & 36.08 & $100.96^{b}$ & 259 & 144.12 & 403.12 & 27.87 & 17.53 & 52.99 \\
\hline
\end{tabular}

$\mathrm{F}=90.7538$ $\mathrm{P}=0.0000 * * *$

$\operatorname{LSD}_{0.05}=23.0033$ 


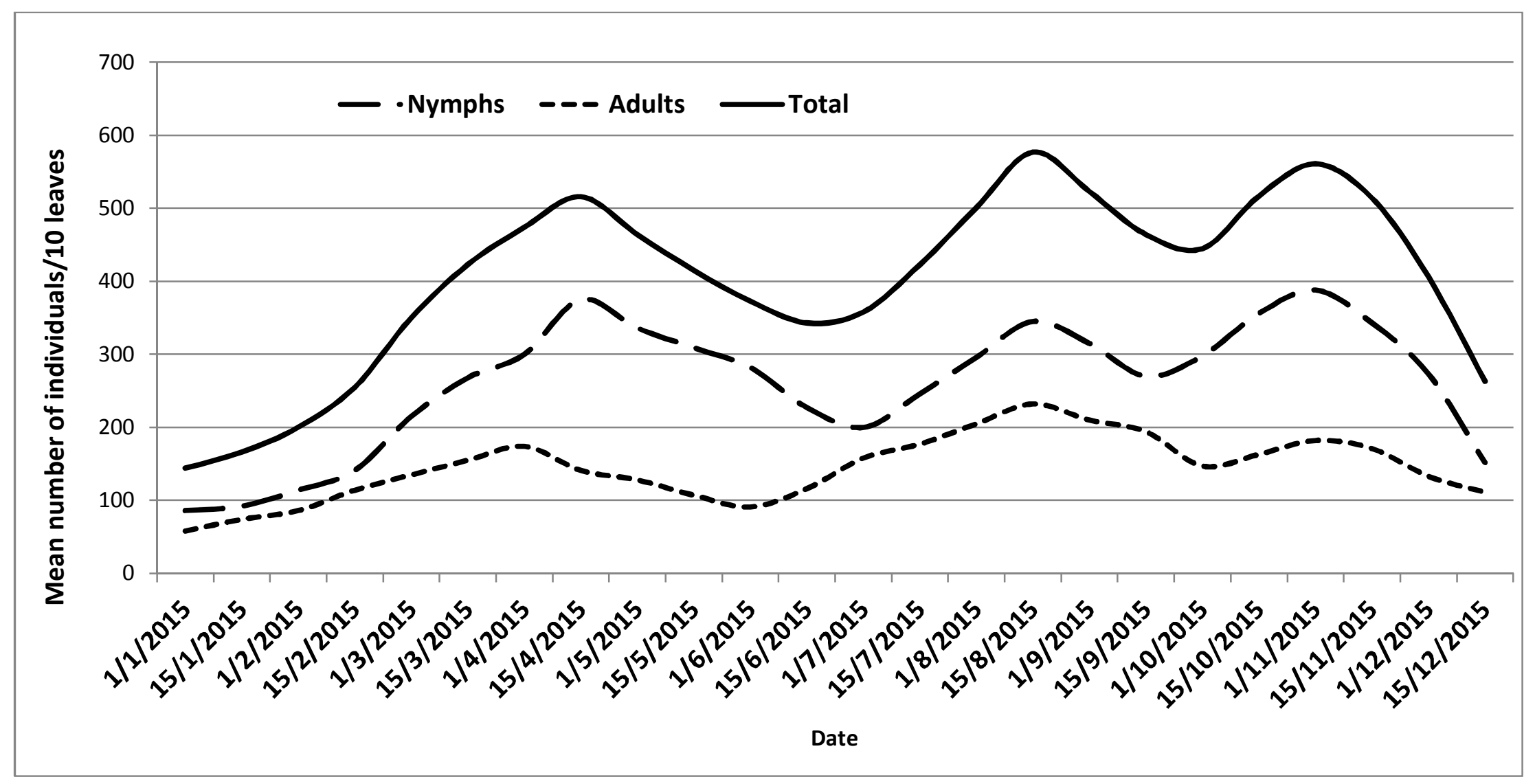

Fig. 2. Half monthly mean counts of Insulaspispalliduladifferent stages, at Fisher mango orchard, Giza, Governorate during 2015 year. 
Differences in susceptibility of various mango cultivars to scale insects had reported by several studies. Salem et al., (2007) showed that, population densities of the I. seychellarum on leaves of Sultani, Baladi, Hendi, Ewaisi and Alphonso mango cultivars were significantly different. They concluded that, Alphonso was completely resistant, while Sultani was highly susceptible to $I$. seychellarum and the order of susceptibility of the studied mango cultivars to $I$. seychellarum could be arranged in descending order as follows: Sultani > Baladi > Hendi > Ewaisi > Alphonso and the levels of susceptibility of mango cvs. for the mealybug, $I$ seychellarum depend on the combined action of leaf nutrients, inhibitors, leaf properties and secondary metabolites. On other hand, Monzer et al., (2006) reported that, leaf nutrients, inhibitors and leaf properties cannot explain the completely resistant of Alphonso leaves to I. seychellarum infestation. They proved that, Alphonso leaves contain certain repellant or toxic secondary metabolites responsible for their resistance to I. seychellarum infestation. El-Badawy, (2014) reported that, the selected five mango cultivars are not equally susceptible to $I$. seychellarum infestation. Fagrikalan mango trees cultivar (cv.) were highly infested, while trees of Dabsha cv. are approximately complete free from I. seychellarum infestation and the susceptibility levels of mango cultivars to $I$. seychellarum could be arranged in descending order as follows: Fagrikalan >Alphonso-Naser >Baladi > Hendi > Dabsha.

However, the preference of $I$. pallidula to Hendi leaves and avoidance of Fagrikalan leaves can be interpreted by presences of leaf secondary metabolites especially essential oils, which are the most important secondary metabolites. The insecticidal or repellent activities of some essential oils of the high susceptible Fagrikalan cv. and the completely tolerable Dabsha cv. against $I$. pallidula revealed that, the chemical composition of essential oils plays an important role in this concern Number and duration of annual field generations:

The number of annual generations of $I$. pallidula during the two years on Mango trees is graphically illustrated in Figures. (1 and 2). I. pallidula had three overlaping generations; the first generation took about four months and half, started from $1^{\text {st }}$ of January till the mid of May 2014 (the maximum number of nymphs occurred on the first of April). Duration of the second generation was nearly two months and half (extended from $1^{\text {st }}$ of June till the mid of August), its peak was indicated on mid of July. Third generation was indicated on mid September till the mid December. Its peak was recorded on $1^{\text {st }}$ October. This means that both second and third generations continued over 70 days each compared with the first generation which continued for 135 days. 


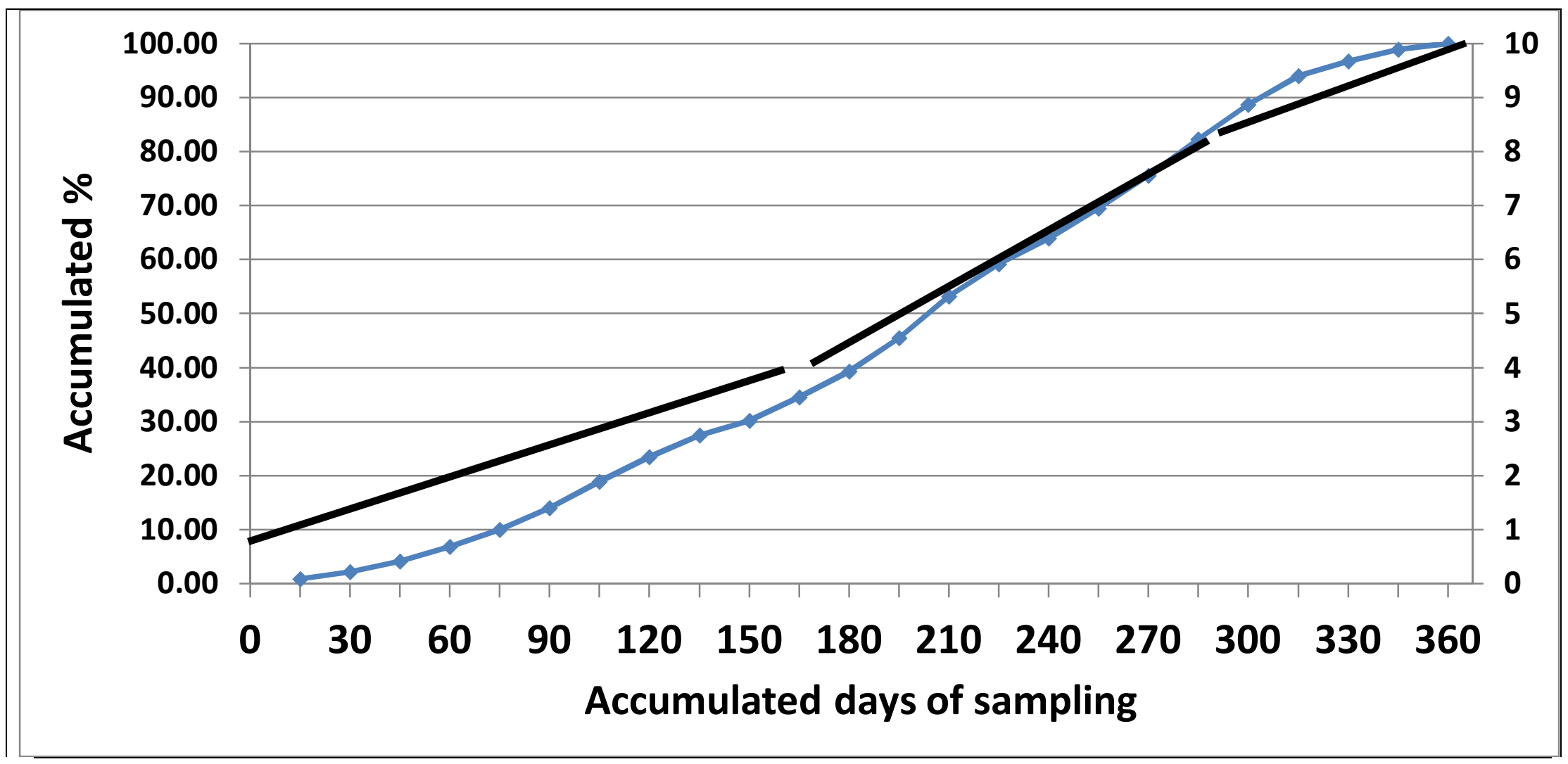

Fig. 3. Annual generations and their durations of Insulaspispallidulaon mango trees, at Giza, Governorate during the firstyear (2014). 


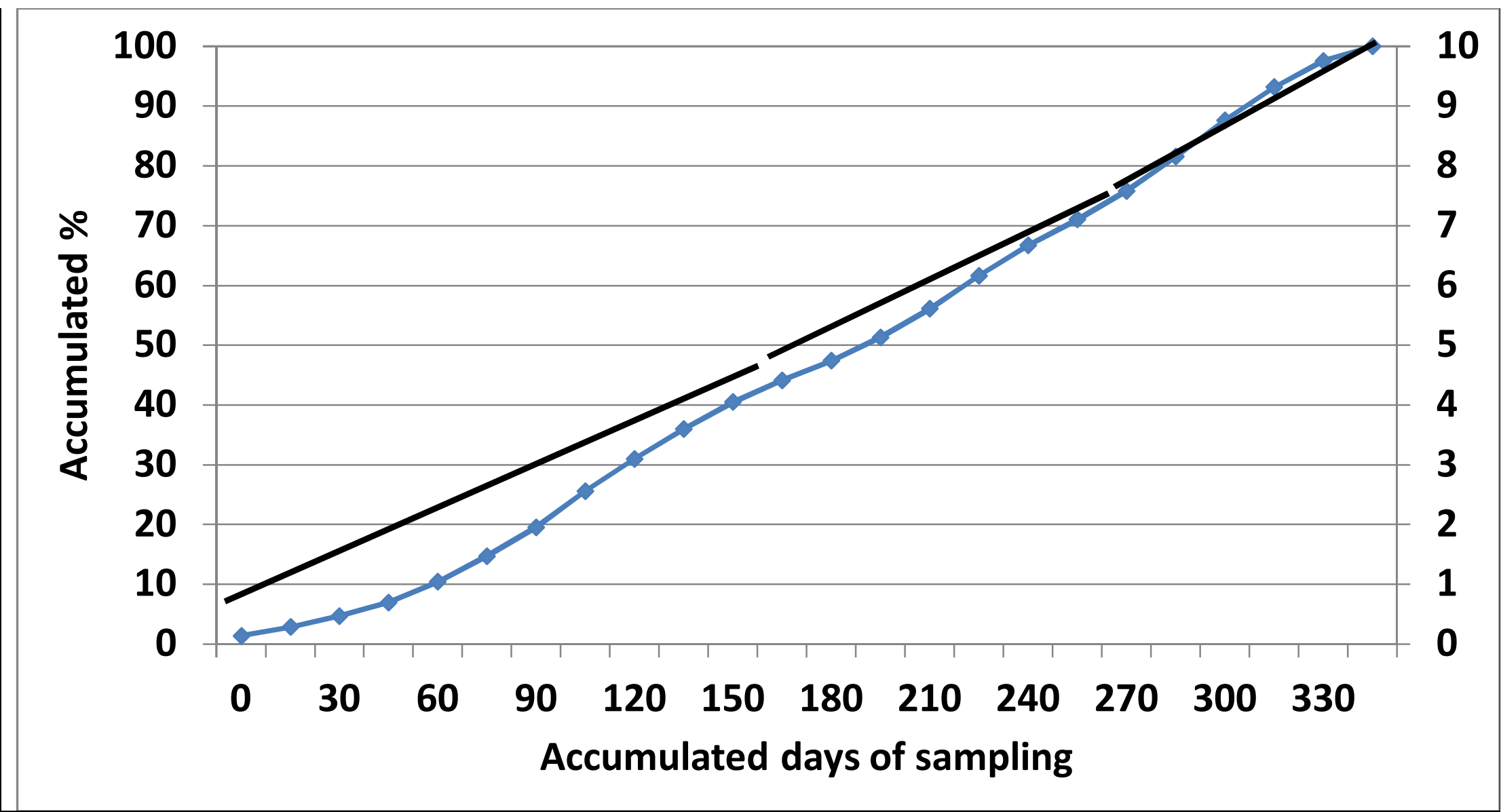

Fig. 4. Annual generations and their durations of Insulaspispallidulaon mango trees, at Giza, Governorate during the secondyear (2015). 
As for the results of the second year 2015 (Fig, 2); I. pallidula showed the same trend and had three generations. The duration of the first one was about six months and a half (extended from $1^{\text {st }}$ of January to $1^{\text {st }}$ of July) its peak attained on the mid of April. The second generation lasted for about two months from mid July to mid September, with the peak on the mid August. The third generation took about three months and half (from $1^{\text {st }}$ October till mid December) its peak was evident in November.

These results are consistent with that obtained by Ali, (2010) stated that the Maskell scale, L. pallidula had three annual generations per year which recorded at winter, spring and autumn, the highest generation was autumn generation during the first year and winter generation during the second one. Elwan, (2005) recorded three annual generations for $L$. pallidula. Also, these results were in agreement with Salama and Hamdy, (1973) reported that L. pallidula had three generations per year; the $1^{\text {st }}$ in January, the $2^{\text {nd }}$ in April and the third one in October. This differences it depending on the host plant and the geographical location. The abundance fluctuations of the $I$. pallidula on Mango trees are not identical from habitat to the other and from the seasonal period to the other. Contrary, Hassan, (1998), showed that I. pallidula have four generations per year on mango fruit trees.

Using our findings three periods are recommended for control of this insect population (depending on population determination). The first period is during Apr. 15 to 30 to compact the first generation coming out of over wintering one. The second one is during Jul. 15 to 30 to protect the new formed fruits. The third one is during Sept. 15 to 30 to reduce the over wintering ones. Finally, from the previous ecological studies we could concluded that the scale insects should be controlled after knowing the following items the number of generations of the pest and the highest one. The climatic factors and the natural enemies effect on the population of the scale insects.

Effect of prevailing hygrothermic conditions on the population densities of

\section{I. pallidula :}

The measured relationships between the population densities of $I$. pallidula and the main weather factors were showed in Table, (4). Daily temperature (maximum and minimum temperatures) and daily relative humidity were studied during two studied years, (2014-2015) in Giza governorate as in table, (4).

\section{1) Effect of daily maximum temperature:}

Results in the tables, ( 3 and 4 ) showed that, there are positive significant correlation between the total insect population activity and maximum temperature $(r=0.806$ and 0.642$)$ in both years, (2014-2015). The partial regression coefficient 
value (P.reg= 16.880 and 13.877 ) showed highly positive significant in the two years $(t=7.70$ and 4.38$)$.

\section{2) Effect of the night minimum temperature:}

The effect of minimum temperature on the total population during two years of study (Table, 4) indicated highly positive significant correlation during the two years $(r=0.828$ and 0.625$)$ respectively. The single effect of this factor on the total population activity appeared from (P.reg $=7.73$ and 5.929) which was positive significant effect ( $t=8.29$ and 4.30 ).

\section{3) Effect of daily mean relative humidity:}

Daily mean relative humidity (Table, 4 ) had negative relation, insignificant on the total population $(r=-0.379)$ in $1^{\text {st }}$ year but positive relation insignificant $(r=$ 0.158). The single effect of this factor on the total population activity appeared from the partial regression coefficient value (P.reg $=58.85$ and 49.105) which was positive insignificant effect $(t=-1.88$ and 0.65$)$ in both years.

\section{4) The combined effect of daily mean temperature and humidity:}

The combined effect of climatic factors on the maskell scale, I. pallidula during the two years of study (Table, 4) was significant ( $F=14.193$ and 9.110) and the explained variance (E.V) presented (68\% and $57.7 \%)$ during the two years of study.

Our results were supported by Ali, (2010) their results indicated that the maximum and minimum temperature gave highly significant effect on $L$. pallidula population. Also, Hassan, (1998), stated that the maximum and minimum temperatures were significant on the population of $I$. pallidula, while the relative humidity factor had not significant correlation. 
Table 4. Effect of both temperature and relative humidity on Insulaspis pallidula total population on mango leaves at El-Saff, Giza Governorate, Egypt during the two studied years (2014-2015).

\begin{tabular}{|c|c|c|c|c|c|c|}
\hline \multirow{3}{*}{$\begin{array}{l}\text { Statistical } \\
\text { Parameters }\end{array}$} & \multicolumn{3}{|c|}{ First year (2014) } & \multicolumn{3}{|c|}{ Second year (2015) } \\
\hline & \multicolumn{2}{|c|}{ Temperature } & \multirow[t]{2}{*}{ R.H.\% } & \multicolumn{2}{|c|}{ Temperature } & \multirow[t]{2}{*}{ R.H.\% } \\
\hline & Tmax. & Tmin. & & Tmax. & Tmin. & \\
\hline \multicolumn{7}{|l|}{ Simple correlation } \\
\hline Corr.Coef.(r) & $0.806 \pm 0.13$ & $0.828 \pm 0.12$ & $-0.379 \pm 0.19$ & $0.642 \pm 0.16$ & $0.625 \pm 0.17$ & $0.158 \pm 0.21$ \\
\hline Probability(p) & $<0.0001$ & $<0.0001$ & 0.0680 & 0.0007 & 0.0011 & 0.4597 \\
\hline Correlation significant & Yes & Yes & No & Yes & Yes & No \\
\hline \multicolumn{7}{|l|}{ Partial Regression } \\
\hline Partial Regres. Coef (b) & $16.88 \pm 3.88$ & $7.733 \pm 3.20$ & $58.855 \pm 7.31$ & $13.877 \pm 7.59$ & $5.929 \pm 5.18$ & $49.105 \pm 11.18$ \\
\hline Regression Coefficient $r^{2}$ & 0.649 & 0.686 & 0.143 & 0.412 & 0.391 & 0.025 \\
\hline F-value & 40.681 & 48.112 & 3.683 & 15.438 & 14.126 & 0.566 \\
\hline Probability $(p)$ & $<0.0001$ & $<0.0001$ & 0.0680 & 0.0007 & 0.0011 & 0.4597 \\
\hline Regression significant & Yes & Yes & No & Yes & Yes & No \\
\hline & \multicolumn{6}{|c|}{ Combined factors } \\
\hline E.V (Explained variance) & & 68.00 & & & 57.7 & \\
\hline
\end{tabular}




\section{REFERENCES}

1. Ali, S.A. 2010. Ecological studies of scale insects infesting mango and guava trees and their control in Qaliobiya governorate. Ph.D. Thesis, Faculty of Science, Ain Shams Univ., Egypt, p 216.

2. Assem. M.S. 1990. Survey and biological studies on some insects attacking certain ornamental plants. Ph.D. Thesis, Fac. Agric., Cairo Univ., Cairo, Egypt, 202p.

3. Costat. 2005. Version 6.311, Copyright(c), CoHort Software, 798 Lighthouse Ave.

4. EI-Masry, H.A. 2004). Cultivation and production of mangoes. Egyptian Ministry of Agriculture, Technical report no. 8/2004. Cairo, Egypt. 123 p.

5. El-Badawy, S.S. 2014. Interpretation of susceptibility phenoamenon of some mango cultivars to Icerya seychellarum (Westwod) (Hemiptera: Monophlebidae). Egypt, J. Agric. Res., 92 (4), 1235-1252.

6. EI-Zohgbi, M. and G. A. Mostafa. 2002. Characterization of the geographic origin of mango pulp from Egypt, Brazil and Puerto Rico by ICP-MS. Zagazig. J. Agric. Res., 28 (3): 629-639.

7. Elwan E. A. H. 1990. Ecological and biological studies on certain insects pests of Coccoidea (Homoptera) infesting mango trees. Ph.D. Thesis, Fac. of Agric., AlAzhar Univ., Egypt p 175.

8. Elwan, E.A.H. 2005. Population dynamics of Maskell scale, Insulaspis pallidula(Green) (Homoptera-Diaspididae), on mango trees in Egypt. Egyptian J. Agric. Res. 2005; 83 (3): 1199-1212.

9. Hassan, N.A. 1998. Ecological studies on Insulaspis pallidula on mango trees., J. Agric. Sci. Mansoura Univ., 23 (8): 3986.

10. Monzer, M. A.; M. S. Salem, M. I. El-said and A. Melegi. 2006. Resistance of Alphonso mango-cultivar to the margarodid mealybug, Icerya seychellarum (Westwood) in relation to leaf quality: I. Leaf secondary metabolites. Egypt $J$. Agric. Res., 84 (1): 17-29.

11. Radwan S. 2003. Toxicological studies on some scale insects infested mango and guava trees. Ph. D. Thesis, Fac. Agric., Cairo Univ. 1-221.

12. Salama, H.S. and M.K. Hamdy. 1973. Studies on the population dynamic of Lepidosaphes pallidi (Green). I-Distribution on mango trees Z Angew Entomol., 73:82-92.

13. Salem, M. I.; M. I.El-Said, A. Melegi and M. A. Monzer. 2007. Susceptibility of Plants attracts parasitic wasps to defend themselves against insect pests by releasing (Z) 3-Hexenol. PLOS ONE 2(9): e852. 
حصر الحشرات القشرية والبق الدقيقي علي أثجار المانجو ودراسات إيكولوجية لحشرة الماتجو المحاربة Insulaspis pallidula (Green) في محافظة الجيزة

$$
\begin{aligned}
& \text { مها إبراهيم إبفون عبد الله عادل سراج سامي البدوي } \\
& \text { مركز البحوث الزر اعية - معهد بحوث وقاية النباتات -V شارع نادي الصيد- الدقي- الجيزة. }
\end{aligned}
$$

يهدف هذا البحث إلي حصر للحشرات القشرية و البق الدقيقي في مزرعة للمانجو بمنطقة

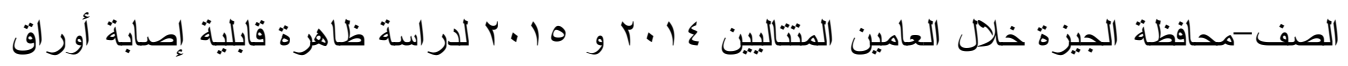

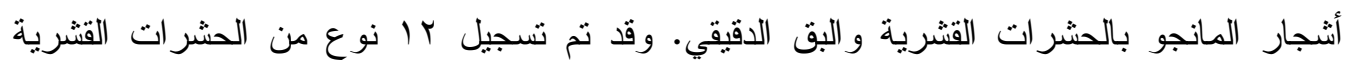

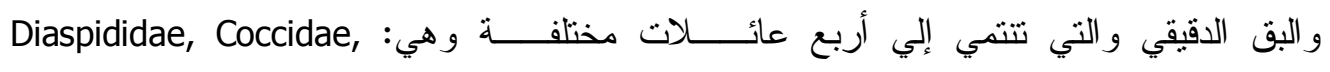
Monophlebidae and Pseudococcidae. الثهرية وجد أن البـــق الــدقيقي Icerya seychellarum كان الأعلي كثافة في التعداد والأكثر خــورة علي أور اق أثنــار المــانجو يليه حشرة المانجو المحاربة Insulaspis pallidula Hemiberlesia lataniae ثilifia acuminata

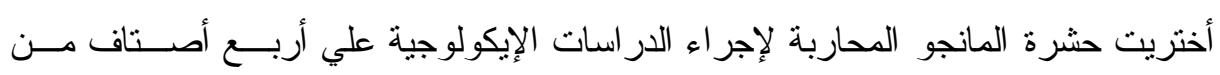

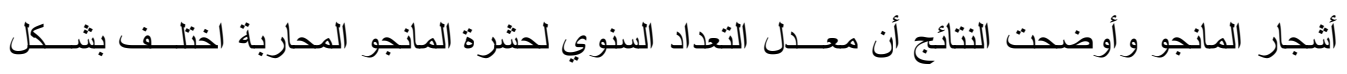

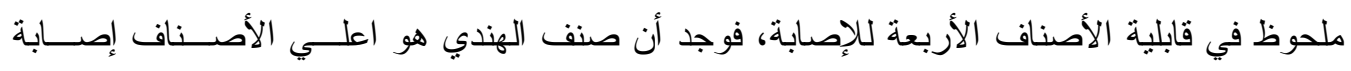

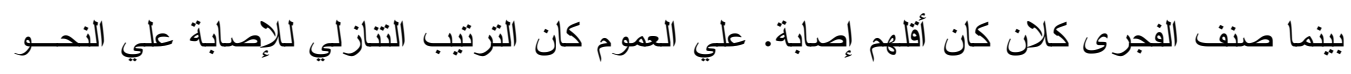

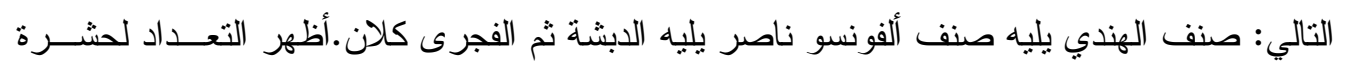

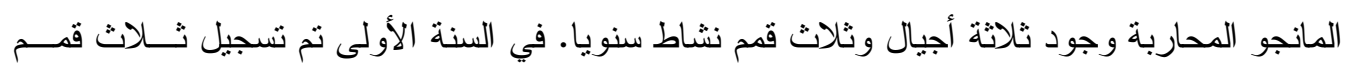

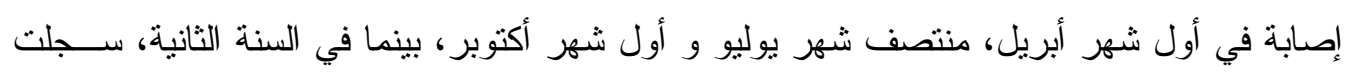

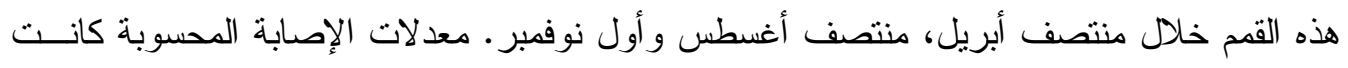

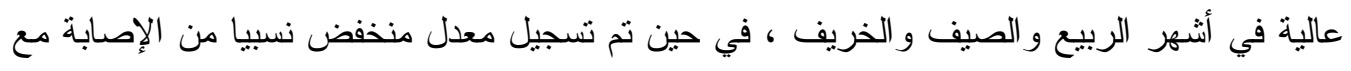
أنشهر الثنتاء في كل سنة. 